\title{
Evaluation of BacT/Alert FAN Plus Bottles for the Culture of Peritoneal Dialysate
}

\author{
Min-Seung Park', In Young Yoo', On-Kyun Kang', Jung Eun Lee ${ }^{2}$, \\ Dae Joong Kim², Hee Jae Huh', Nam Yong Lee ${ }^{1}$ \\ ${ }^{1}$ Department of Laboratory Medicine and Genetics, ${ }^{2}$ Division of Nephrology, Department of Medicine, \\ Samsung Medical Center, Sungkyunkwan University School of Medicine, Seoul, Korea
}

Background: A major complication of peritoneal dialysis (PD) is peritonitis, and bacterial culture of PD effluent in a blood culture bottle is the preferred technique for diagnosis of peritonitis. In this study, we compared dialysate inoculation and culture using the BacT/AlerT ${ }^{\circledR}$ Fastidious Antimicrobial Neutralization Plus blood culture bottles (FAN Plus; bioMérieux, France) to the conventional centrifugation culture method.

Methods: A total of 170 PD effluents were simultaneously processed by the conventional centrifugation culture method and by culture using FAN Plus media with two different inoculation procedures: inoculation after centrifugation and direct bedside inoculation.

Results: Of the 52 cultures that were positive on at least one of the culture methods, 27 samples were positive on conventional centrifugation. However, 46 samples showed growth following inoculation into the FAN Plus media after centrifugation, and 47 samples were positive on the direct FAN Plus inoculation method. Using the case definition for PD peritonitis to classify samples, sensitivity of the conventional method was $50.0 \%(95 \% \mathrm{Cl}, 33.7-66.3 \%)$, whereas the sensitivity of the FAN Plus media was $78.9 \%$ $(95 \% \mathrm{Cl}, 62.2-89.9 \%)$ by inoculation after centrifugation and $86.8 \%(95 \% \mathrm{Cl}, 71.1-95.1 \%)$ by direct inoculation. Use of both inoculation methods with FAN Plus media resulted in $92.1 \%$ sensitivity $(95 \% \mathrm{Cl}, 89.2-99.9 \%)$. Conclusion: Culture using FAN Plus media demonstrated a superior bacterial recovery rate to the conventional centrifugation culture method. A combination of the two inoculation methods with FAN Plus media is recommended for the best diagnostic yield, while direct inoculation alone can be useful due to its simplicity and cost-effectiveness. (Ann Clin Microbiol 2019;22:90-95)

Key Words: BacT/AlerT 3D system, Centrifugation, Culture media, FAN Plus blood culture bottle, Peritoneal dialysis, Peritonitis

\section{INTRODUCTION}

Continuous ambulatory peritoneal dialysis (PD) has become the preferred method of home dialysis for patients with end-stage renal failure [1]. The most concerning complication of $\mathrm{PD}$ is peritonitis, which is the direct or major contributing cause of death in about $16 \%$ of PD patients and accounts for antibiotic use in many patients undergoing PD [2,3]. Therefore, identification of the causative organism and its antibiotic sensitivities not only helps guide the choice of antibiotic, but also often sug- gests the possible source of infection [3].

International Society for Peritoneal Dialysis (ISPD) guidelines recommend that blood-culture bottles be used for bacterial culture of PD effluent and also suggest that centrifugation of dialysate effluent prior to inoculation can increase the microbial yield [3]. Specifically, the ISPD 2016 guidelines suggest use of several specimen processing and culture methods including direct inoculation into blood-culture bottles, centrifuging PD fluid followed by inoculation into solid culture media or blood-culture media, and the lysis centrifugation technique [3].

Received 27 April, 2019, Revised 18 June, 2019, Accepted 18 June, 2019

Correspondence: Nam Yong Lee, Department of Laboratory Medicine and Genetics, Samsung Medical Center, Sungkyunkwan University School of Medicine, 81 Irwon-ro, Gangnam-gu, Seoul 06351, Korea. (Tel) 82-2-3410-2706, (Fax) 82-2-3410-2719, (E-mail) micro.lee@samsung.com

Correspondence: Hee Jae Huh, Department of Laboratory Medicine and Genetics, Samsung Medical Center, Sungkyunkwan University School of Medicine, 81 Irwon-ro, Gangnam-gu, Seoul 06351, Korea. (Tel) 82-2-3410-1836, (Fax) 82-2-3410-2719, (E-mail) pmhhj77@gmail.com

(c) The Korean Society of Clinical Microbiology

(․) This is an Open Access article distributed under the terms of the Creative Commons Attribution Non-Commercial License (http://creativecommons.org/licenses/by-nc/4.0) which permits unrestricted non-commercial use, distribution, and reproduction in any medium, provided the original work is properly cited. 
Numerous studies have documented the advantage of using blood-culture bottle kits to improve the microbial yield of peritoneal fluid culture [2,4-9]. The widely used BacT/AlerT ${ }^{\circledR} 3 \mathrm{D}$ system (BacT/AlerT system; bioMérieux, Marcy l'Etoile, France) is an automated blood culture system that can be used in combination with BacT/AlerT ${ }^{\circledR}$ Fastidious Antimicrobial Neutralization Plus blood culture bottles (FAN ${ }^{\circledR}$ Plus bottles; bioMérieux). FAN Plus is a resin-based media containing antibiotic-binding polymeric beads in place of charcoal-based antimicrobial neutralization (FAN blood culture media). Although various automated blood culture systems using blood-culture bottle kits have been evaluated for culture of PD fluid [2,4,7-11], studies assessing recently developed blood-culture bottles and media are lacking.

In this study, we evaluated the performance of inoculation and culture of PD effluent using FAN Plus blood culture media. We compared the outcome of culture in the FAN Plus media by two different inoculation procedures-inoculation after centrifugation and direct inoculation-to the conventional centrifugation culture method.

\section{MATERIALS AND METHODS}

\section{Patient population}

This study was conducted at a tertiary-care hospital in Seoul, Korea and was approved by the Institutional Review Board of Samsung Medical Center (approval number: 2018-07-174). PD effluent samples submitted to the laboratory between Jan 2014 to May 2018 were included in this study. A total of 170 effluents from 93 patients were evaluated. All samples were simultaneously processed by the conventional centrifugation culture method and by two different inoculation methods into the FAN Plus blood culture media: 1) inoculation after centrifugation and 2) direct bedside inoculation.

\section{PD effluent processing methods and microbial identification}

The conventional centrifugation culture method and inoculation into the FAN Plus after centrifugation were conducted using centrifuged sediment inoculation as follows. The $50 \mathrm{~mL}$ of PD effluents were centrifuged at $3,000 \times \mathrm{g}$ for 15 minutes, followed by resuspension of the sediment in $3-5 \mathrm{~mL}$ of supernatant. The 1.5-2.5 mL of resuspended sediment was inoculated into FA Plus (aerobic) blood culture bottles and FN Plus (anaerobic) blood culture bottles, respectively. The remaining resuspended sediment was inoculated into conventional cul- ture media (5\% sheep's blood agar, MacConkey agar, Brucella agar, and thioglycolate broth for anaerobes). The direct bedside FAN Plus inoculation was done by directly adding $5-10 \mathrm{~mL}$ peritoneal dialysis effluent into FA Plus and FN Plus blood culture bottles at bedside.

Conventional media cultures were examined by standard protocols and growth was monitored for up to 7 days [12]. FAN Plus bottles were incubated in the BacT/Alert 3D system at $36^{\circ} \mathrm{C}$ with continuous monitoring for 5 days. When bacterial growth was detected by $\mathrm{CO}_{2}$ production, the broth was aspirated for Gram staining and subculture. An aliquot of the FA Plus media cultures was subcultured onto 5\% sheep's blood agar, MacConkey agar, and chocolate agar, and then incubated at $35^{\circ} \mathrm{C}$ in $5 \% \mathrm{CO}_{2}$. For FN Plus media cultures, an aliquot of the broth was subcultured onto 5\% sheep's blood agar, MacConkey agar, and brucella agar, and then incubated in an anaerobic chamber (Bactron II \& IV, Sheldon Manufacturing Inc., Cornelius, OR, USA). Each isolated organism was identified using the Vitek 2 or Vitek MS system (BioMérieux, Marcy l'Etoile, France).

\section{Diagnosis of peritonitis}

All clinical findings of patients were assessed by medical record review. In accordance with the ISPD guidelines, cases were classified as having PD peritonitis when at least two of the following were true: 1) clinical features consistent with peritonitis, such as abdominal pain, cloudy PD effluent; 2) PD effluent with white cell count $>100 / \mu \mathrm{L}$ and with more than $50 \%$ neutrophils; 3) positive PD culture [3]. Follow-up cultures for the same patient within the same infectious event were excluded from analyses of diagnostic sensitivity and specificity.

\section{Statistical analysis}

The recovery rates of microorganisms in culture using the FAN Plus media were compared to those using the conventional centrifugation culture method by McNemar's test. Diagnostic sensitivity and specificity of each culture method were calculated on the basis of peritonitis diagnosis by the ISPD definition. A $P$ value less than 0.05 was considered statistically significant. For statistical evaluations, VassarStats (http://vassarstats. net) was used.

\section{RESULTS}

Among 170 PD effluent samples, 52 showed culture-positive 
results by at least one culture method. A total of 27 samples were culture-positive following the conventional centrifugation culture method, 46 samples showed growth in the FAN Plus media inoculated after centrifugation, and 47 samples were positive following direct inoculation into FAN Plus media (Table 1). The use of both inoculation methods with FAN Plus media resulted in culture positivity of five additional samples. Compared to the conventional culture method, significantly more isolates were recovered from each method using FAN Plus media: FAN Plus inoculation after centrifugation and direct FAN Plus inoculation $(P$ value $<0.001)$.
The microorganisms isolated by each method are listed in Table 2. Of the total 52 culture-positive samples, 75 different bacterial organisms were detected and polymicrobial growth occurred in 11 samples. None of the isolates from culture-positive samples were found only in the conventional culture method. However, a total of 40 isolates were found only in the cultures with the FAN Plus media. Among those, eight isolates were grown only using the method of FAN Plus inoculation after centrifugation. These included three Enterobacteriaceae, two enterococci, and three other bacteria. Fourteen isolates were recovered only from the direct FAN Plus inoculation method and in-

Table 1. The recovery of microorganisms following culture methods in FAN Plus media compared the conventional centrifugation culture method

\begin{tabular}{|c|c|c|c|c|c|}
\hline \multirow{2}{*}{ Method } & \multirow{2}{*}{ Result } & \multicolumn{3}{|c|}{ Conventional centrifugation culture (no. of specimens) } & \multirow{2}{*}{$P$ value } \\
\hline & & Positive & Negative & Total & \\
\hline \multirow{3}{*}{$\begin{array}{l}\text { FAN Plus inoculation after } \\
\text { centrifugation }\end{array}$} & Positive & 27 & 19 & 46 & \multirow[t]{3}{*}{$<0.001$} \\
\hline & Negative & 0 & 124 & 124 & \\
\hline & Total & 27 & 143 & 170 & \\
\hline \multirow[t]{3}{*}{ Direct FAN Plus inoculation } & Positive & 26 & 21 & 47 & \multirow[t]{3}{*}{$<0.001$} \\
\hline & Negative & 1 & 122 & 123 & \\
\hline & Total & 27 & 143 & 170 & \\
\hline \multirow{3}{*}{$\begin{array}{l}\text { Combination of two methods } \\
\text { using FAN Plus media }\end{array}$} & Positive & 27 & 25 & 52 & \multirow[t]{3}{*}{$<0.001$} \\
\hline & Negative & 0 & 118 & 118 & \\
\hline & Total & 27 & 143 & 170 & \\
\hline
\end{tabular}

Table 2. Microorganisms isolated from each culture method

\begin{tabular}{|c|c|c|c|c|}
\hline \multirow{2}{*}{ Organism } & \multicolumn{4}{|c|}{ No. of organisms detected } \\
\hline & $\begin{array}{c}\text { Conventional } \\
\text { centrifugation culture }\end{array}$ & $\begin{array}{l}\text { FAN Plus inoculation } \\
\text { after centrifugation }\end{array}$ & $\begin{array}{l}\text { Direct FAN Plus } \\
\text { inoculation }\end{array}$ & Total \\
\hline Gram positive & 12 & 27 & 29 & 34 \\
\hline Staphylococcus aureus & 4 & 5 & 5 & 5 \\
\hline Coagulase-negative staphylococci & 2 & 5 & 6 & 7 \\
\hline Enterococcus faecium & 1 & 2 & 3 & 3 \\
\hline Enterococcus faecalis & 1 & 4 & 5 & 6 \\
\hline Other Enterococcus spp. & 1 & 6 & 4 & 6 \\
\hline Streptococcus spp. & 2 & 2 & 2 & 3 \\
\hline Other & 1 & 3 & 4 & 4 \\
\hline Gram negative & 15 & 30 & 26 & 33 \\
\hline Escherichia coli & 3 & 5 & 5 & 6 \\
\hline Citrobacter freundii & 1 & 6 & 5 & 6 \\
\hline Enterobacter spp. & 1 & 6 & 4 & 6 \\
\hline Klebsiella pneumoniae & 0 & 0 & 1 & 1 \\
\hline Pseudomonas aeruginosa & 7 & 8 & 7 & 8 \\
\hline Other & 3 & 5 & 4 & 6 \\
\hline Anaerobes & 4 & 4 & 4 & 8 \\
\hline Clostridium spp. & 1 & 1 & 2 & 3 \\
\hline Bacteroides spp. & 2 & 2 & 1 & 3 \\
\hline Prevotella spp. & 1 & 1 & 1 & 2 \\
\hline
\end{tabular}


Table 3. Diagnostic sensitivity and specificity of each method based on the diagnostic criteria of PD peritonitis

\begin{tabular}{|c|c|c|c|c|c|}
\hline \multirow[b]{2}{*}{ Tests } & \multirow[b]{2}{*}{ Result } & \multicolumn{2}{|c|}{ PD peritonitis } & \multirow{2}{*}{$\begin{array}{l}\text { Sensitivity }(\%) \\
(95 \% \mathrm{CI})\end{array}$} & \multirow[b]{2}{*}{$\begin{array}{c}\text { Specificity }(\%) \\
(95 \% \mathrm{CI})\end{array}$} \\
\hline & & $\begin{array}{l}\text { Positive } \\
(\mathrm{N}=38)\end{array}$ & $\begin{array}{l}\text { Negative } \\
(\mathrm{N}=56)\end{array}$ & & \\
\hline \multirow[t]{2}{*}{ Conventional centrifugation culture } & Positive & 19 & $1 *$ & $50.0(33.7-66.3)$ & 98.2 (89.2-99.9) \\
\hline & Negative & 19 & 55 & & \\
\hline \multirow{2}{*}{$\begin{array}{l}\text { FAN Plus inoculation after } \\
\text { centrifugation }\end{array}$} & Positive & 30 & $1 *$ & $78.9(62.2-89.9)$ & $98.2(89.2-99.9)$ \\
\hline & Negative & 8 & 55 & & \\
\hline \multirow[t]{2}{*}{ Direct FAN Plus inoculation } & Positive & 33 & 0 & $86.8(71.1-95.1)$ & $100(92.0-100)$ \\
\hline & Negative & 5 & 56 & & \\
\hline \multirow{2}{*}{$\begin{array}{l}\text { Combination of two methods using } \\
\text { FAN Plus media }\end{array}$} & Positive & 35 & $1 *$ & 92.1 (77.5-97.9) & $98.2(89.2-99.9)$ \\
\hline & Negative & 3 & 55 & & \\
\hline
\end{tabular}

*Enterococcus faecalis from the same specimen.

cluded four anaerobes, three enterococci, two Enterobacteriaceae, two coagulase-negative staphylococci, and three other bacteria.

Of the total 170 PD effluent samples evaluated, 74 were considered follow-up cultures. After excluding two cases with insufficient medical information, 94 nonreplicate samples were classified according to the diagnostic criteria for PD peritonitis. A total of 38 were from patients classified as having peritonitis, and the remaining 56 were from patients without peritonitis (Table 3). On the basis of these classifications, sensitivity of the conventional method was $50.0 \%$ (95\% confidence interval [CI], $33.7-66.3 \%)$. However, the sensitivity of inoculation after centrifugation using FAN Plus media was 78.9\% (95\% CI, $62.2-89.9 \%$ ) and the sensitivity of direct FAN Plus inoculation was $86.8 \%$ (95\% CI, 71.1-95.1\%). Use of both inoculation methods with FAN Plus media resulted in $92.1 \%$ sensitivity (95\% CI, 77.5-97.9\%). Specificities of each method were over $98 \%$.

\section{DISCUSSION}

Previous studies have shown that PD effluent culture methods using automated blood culture systems have several advantages, including increased sensitivity and earlier detection of microbial growth due to continuous monitoring [2,6,13-15]. Furthermore, several recent studies have reported that the use of resin-based blood culture media significantly improves recovery rates compared to charcoal-based media [16-19]. This has been attributed to the improved binding kinetics of the resin-based media for a variety of antimicrobial agents [19]. Based on these results, the resin-based medias, including the FAN Plus media, have been thoroughly evaluated for culturing of blood and several types of sterile body fluids [20-24]. However, the utility of this method had not previously been evaluated for PD effluent culture. In the present study, culture using the FAN Plus media has superior recovery rates compared to the conventional culture method. Moreover, two methods using FAN Plus media, inoculation after centrifugation and direct inoculation, resulted in comparable recovery rates.

Recent ISPD guidelines suggest that sampling and culture methods be reviewed and improved if more than $15 \%$ of peritonitis episodes are culture-negative [3]. Also, the guidelines describe that bacterial yield from peritoneal fluid culture is enhanced by either inoculating the fluid directly into blood-culture bottle kits, centrifuging PD fluid and culturing the pellet, or the lysis centrifugation technique $[3,8]$. A number of novel diagnostic techniques have also been explored, including biomarker assays, nucleic acid amplification, and 16S rRNA gene sequencing, but these techniques are difficult to implement for routine testing in clinical laboratories $[3,25,26]$. In our study, the use of both inoculation after centrifugation and direct inoculation into FAN Plus media resulted in less than $8 \%$ of culture-negative peritonitis. Therefore, incorporation of the two culture methods using the FAN Plus media is recommended for diagnosis of PD peritonitis for the best recovery rate. In the practical field, single method of direct inoculation can be useful regarding of the simplicity and cost-effectiveness.

Consistent with previously reported results, coagulase-negative staphylococci were the most frequently isolated Gram-positive bacteria and Enterobacteriaceae, including Escherichia coli, Citrobacter freundii, Klebsiella pneumoniae, and Enterobacter spp., were the most frequently isolated Gram-negative bacteria (data not shown) from nonreplicated peritonitis cases 
$[13,27,28]$.

This study has several limitations inherent to retrospective analyses. Specifically, we cannot compare the time required to detect growth by each culture method or draw conclusions regarding the appropriate incubation period in this study. Also, we cannot confirm the contamination at the bacterial culture procedure. It is difficult to distinguish true infection from contamination, especially when single culture method shows positive culture results. In this study, we considered the isolated bacteria as a causative organisms of PD peritonitis through clinical review of each case.

In summary, we compared culture using the FAN Plus media to the conventional centrifugation culture method for the diagnosis of PD peritonitis. The culture methods using the FAN Plus media-inoculation after centrifugation and direct inoculationhad a superior recovery rate compared to the conventional centrifugation culture method. The two different inoculation methods using FAN Plus media resulted in comparable recovery rates. Use of both inoculation methods with the FAN Plus media is recommended for the best diagnostic yield, and single method of direct inoculation can be useful regarding of the simplicity and cost-effectiveness.

\section{AUTHOR'S DISCLOSURES OF POTENTIAL CONFLICTS OF INTEREST}

No potential conflicts of interest relevant to this article were reported.

\section{ACKNOWLEDGMENTS}

We are grateful to the advanced practice nurse of peritoneal dialysis, Jaesun Moon.

\section{REFERENCES}

1. Al-Allak A, Jones R, Stiff R, Dharmasena D, Morris-Stiff G. Long-term outcome of continuous ambulatory peritoneal dialysis (CAPD) peritonitis: surgery can be avoided. Ann R Coll Surg Engl 2009;91:118-22.

2. Yoon SH, Choi NW, Yun SR. Detecting bacterial growth in continuous ambulatory peritoneal dialysis effluent using two culture methods. Korean J Intern Med 2010;25:82-5.

3. Li PK, Szeto CC, Piraino B, de Arteaga J, Fan S, Figueiredo AE, et al. ISPD peritonitis recommendations: 2016 update on prevention and treatment. Perit Dial Int 2016;36:481-508.

4. Alfa MJ, Degagne P, Olson N, Harding GK. Improved detection of bacterial growth in continuous ambulatory peritoneal dialysis effluent by use of BacT/Alert FAN bottles. J Clin Microbiol 1997;35:862-6.

5. Rayner BL, Williams DS, Oliver S. Inoculation of peritoneal dialysate fluid into blood culture bottles improves culture rates. S Afr Med J 1993;83:42-3.

6. Azap OK, Timurkaynak F, Sezer S, Cağir U, Yapar G, Arslan H, et al. Value of automatized blood culture systems in the diagnosis of continuous ambulatory peritoneal dialysis peritonitis. Transplant Proc 2006;38:411-2.

7. Males BM, Walshe JJ, Garringer L, Koscinski D, Amsterdam D. Addi-Chek filtration, BACTEC, and 10-ml culture methods for recovery of microorganisms from dialysis effluent during episodes of peritonitis. J Clin Microbiol 1986;23:350-3.

8. Iyer RN, Reddy AK, Gande S, Aiyangar A. Evaluation of different culture methods for the diagnosis of peritonitis in patients on continuous ambulatory peritoneal dialysis. Clin Microbiol Infect 2014;20:O294-6.

9. Stokely DJ, Kwan JT, Bending MR, Chin AT, Eisinger AJ. Isolation of organisms in CAPD peritonitis: use of nutrient broth cultures and Bactec blood culture media. J Hosp Infect 1988;11: 77-81.

10. Chow KM, Chow VC, Szeto CC, Law MC, Leung CB, Li PK. Continuous ambulatory peritoneal dialysis peritonitis: broth inoculation culture versus water lysis method. Nephron Clin Pract 2007;105:c121-5.

11. Ahmadi S, Amin-Nordin S, Neela VK, Hamat RA, Goh BL, Nor LA, et al. Evaluation of modified laboratory processes for isolation of bacteria and fungi in continuous ambulatory peritoneal dialysis patients with peritonitis. Perit Dial Int 2015;35:767-9.

12. Thomson RB. Body fluid cultures (excluding blood, cerebrospinal fluid, and urine). In: Leber AL, ed. Clinical Microbiology Procedures Handbook, Fourth Edition. 4th ed, Washington; ASM Press, 2016:3.5.1-3.5.9.

13. Gupta S, Muralidharan S, Gokulnath, Srinivasa H. Epidemiology of culture isolates from peritoneal dialysis peritonitis patients in southern India using an automated blood culture system to culture peritoneal dialysate. Nephrology (Carlton) 2011;16:63-7.

14. Lye WC, Wong PL, Leong SO, Lee EJ. Isolation of organisms in CAPD peritonitis: a comparison of two techniques. Adv Perit Dial 1994;10:166-8.

15. Weinstein MP, Mirrett S, Reimer LG, Wilson ML, Smith-Elekes $\mathrm{S}$, Chuard CR, et al. Controlled evaluation of BacT/Alert standard aerobic and FAN aerobic blood culture bottles for detection of bacteremia and fungemia. J Clin Microbiol 1995;33:978-81.

16. Flayhart D, Borek AP, Wakefield T, Dick J, Carroll KC. Comparison of BACTEC PLUS blood culture media to BacT/Alert FA blood culture media for detection of bacterial pathogens in samples containing therapeutic levels of antibiotics. J Clin Microbiol 2007;45:816-21.

17. Zadroga R, Williams DN, Gottschall R, Hanson K, Nordberg V, Deike $\mathrm{M}$, et al. Comparison of 2 blood culture media shows significant differences in bacterial recovery for patients on antimicrobial therapy. Clin Infect Dis 2013;56:790-7.

18. Kirn TJ, Mirrett S, Reller LB, Weinstein MP. Controlled clinical comparison of BacT/alert FA plus and FN plus blood culture media with BacT/alert FA and FN blood culture media. J Clin Microbiol 2014;52:839-43.

19. Lovern D, Katzin B, Johnson K, Broadwell D, Miller E, Gates A, et al. Antimicrobial binding and growth kinetics in BacT/ALERT ${ }^{\circledR}$ FA Plus and BACTEC ${ }^{\circledR}$ Aerobic/F plus blood culture media. Eur J Clin Microbiol Infect Dis 2016;35:2033-6. 
20. Lee DH, Kim SC, Bae IG, Koh EH, Kim S. Clinical evaluation of BacT/Alert FA plus and FN plus bottles compared with standard bottles. J Clin Microbiol 2013;51:4150-5.

21. De Keukeleire S, Wybo I, Emmerechts K, Piérard D. Performance of BacT/Alert resin-based FN plus bottles compared with BacT/Alert charcoal-based FN bottles for the detection of anaerobes in experimentally seeded blood cultures. Anaerobe 2015;35(Pt B):92-5.

22. Amarsy-Guerle R, Mougari F, Jacquier H, Oliary J, Benmansour $\mathrm{H}$, Riahi J, et al. High medical impact of implementing the new polymeric bead-based BacT/ALERT ${ }^{\circledR}$ FAPlus and FNPlus blood culture bottles in standard care. Eur J Clin Microbiol Infect Dis 2015;34:1031-7.

23. Hughes JG, Vetter EA, Patel R, Schleck CD, Harmsen S, Turgeant LT, et al. Culture with BACTEC Peds Plus/F bottle compared with conventional methods for detection of bacteria in synovial fluid. J Clin Microbiol 2001;39:4468-71.

24. Yoo IY, Chun S, Song DJ, Huh HJ, Lee NY. Comparison of BacT/Alert FAN and FAN plus bottles with conventional medium for culturing cerebrospinal fluid. J Clin Microbiol 2016;54: 2837-40.
25. Chang YT, Wang HC, Wang MC, Wu AB, Sung JM, Sun HS, et al. Rapid identification of bacteria and Candida pathogens in peritoneal dialysis effluent from patients with peritoneal dialysisrelated peritonitis by use of multilocus PCR coupled with electrospray ionization mass spectrometry. J Clin Microbiol 2014; 52:1217-9.

26. Kim SH, Jeong HS, Kim YH, Song SA, Lee JY, Oh SH, et al. Evaluation of DNA extraction methods and their clinical application for direct detection of causative bacteria in continuous ambulatory peritoneal dialysis culture fluids from patients with peritonitis by using broad-range PCR. Ann Lab Med 2012;32: $119-25$.

27. Najafi I, Alatab S, Atabak S, Majelan NN, Sanadgol H, Makhdoomi K, et al. Seventeen years' experience of peritoneal dialysis in Iran: first official report of the Iranian peritoneal dialysis registry. Perit Dial Int 2014;34:636-42.

28. Nishina M, Yanagi H, Kakuta T, Endoh M, Fukagawa M, Takagi A. A 10-year retrospective cohort study on the risk factors for peritoneal dialysis-related peritonitis: a single-center study at Tokai University Hospital. Clin Exp Nephrol 2014;18:649-54.

$=$ 국문초록 $=$

\title{
BacT/Alert FAN Plus 혈액배양병을 이용한 복막투석액 배양능 평가
}

\author{
성균관대학교 의과대학 삼성서울병원 ${ }^{1}$ 진단검사의학교실, ${ }^{2}$ 신장내과학교실 \\ 박민승 ${ }^{1}$, 유인영 ${ }^{1}$, 강온균 ${ }^{1}$, 이정은 ${ }^{2}$, 김대중 $^{2}$, 허희재 $^{1}$, 이남용 $^{1}$
}

배경: 복막투석의 가장 큰 합병증은 복막염이며, 복막염의 진단을 위해 혈액배양병을 이용한 투석액 배양이 권장되고 있다. 저자들은 BacT/AlerT ${ }^{\circledR}$ Fastidious Antimicrobial Neutralization Plus 혈액배양병(FAN Plus; bioMérieux, France)을 이용 한 투석액 배양법과 원심분리를 이용한 고식적인 배양 방법을 비교하고자 하였다.

방법: 총 170 개의 투석액을 고식적인 원심분리 배양 방법과 FAN Plus를 이용한 배양 방법으로 동시에 배양하였다. FAN Plus를 이용한 배양 시 접종은 원심분리 후 접종과 환자 침상 옆 직접 접종 두 가지 방법으로 시행하였다.

결과: 배양양성인 52 개 검체 중 고식적인 원심분리 배양 방법에서는 27 개의 검체가 양성이었다. 원심분리 후 FAN Plus에 접종한 방법에서는 46개의 검체가 양성이었고, 직접 FAN Plus에 접종한 방법에서는 47개의 검체가 양성이었다. 복막염 진단에 대한 민감도는 고식적인 원심분리 방법에서 $50.0 \%(95 \% \mathrm{CI}, 33.7-66.3 \%)$, 원심분리 후 FAN Plus에 접종한 방법에 서 78.9\% (95\% CI, 62.2-89.9\%), 직접 FAN Plus에 접종한 방법에서 86.8\% (95\% CI, 71.1-95.1\%)였다. FAN Plus 혈액배양용 기를 이용한 두 가지 방법을 모두 이용하였을 때의 민감도는 $92.1 \%(95 \% \mathrm{CI}, 89.2-99.9 \%)$ 였다.

결론: FAN Plus를 이용한 배양법은 고식적인 원심분리 배양법보다 우수한 양성률을 보였다. 또한 FAN Plus를 이용한 두 가지 접종방법을 동시에 시행할 때 가장 높은 배양률을 기대할 수 있다. [Ann Clin Microbiol 2019;22:90-95]

교신저자 : 이남용, 06351 , 서울시 강남구 일원로 81

성균관대학교 의과대학 삼성서울병원 진단검사의학교실

Tel: 02-3410-2706, Fax: 02-3410-2719

E-mail: micro.lee@samsung.com

허희재, 06351 , 서울시 강남구 일원로 81

성균관대학교 의과대학 삼성서울병원 진단검사의학교실

Tel: 02-3410-1836, Fax: 02-3410-2719

E-mail: pmhhj77@gmail.com 